\title{
Characterizing a coastal karst aquifer using an inverse modeling approach: The saline springs of Thau, southern France
}

\author{
J.-L. Pinault \\ Service Eau, Bureau de Recherches Géologiques et Minières, Orléans, France
}

N. Doerfliger and B. Ladouche

Service Eau, Bureau de Recherches Géologiques et Minières, Montpellier, France

\author{
M. Bakalowicz \\ Hydrosciences, Maison des Sciences de l'Eau, CNRS et Université Montpellier II, Montpellier, France \\ Received 5 August 2003; revised 31 March 2004; accepted 25 May 2004; published 20 August 2004.
}

[1] A methodological approach using inverse modeling was used to characterize the functioning of the deep and shallow reservoirs of the Thau karst aquifer system. Three springs were monitored at the convergence of rising saline water diluted with shallow groundwater in karst conduits and unmixed shallow groundwater that behaves as confined groundwater. In such a method, impulse responses of flow and fluxes are combined in order to separate hydrographs. The model explains the salinity and hydraulic head variations of the submarine and inland springs. It confirms and improves the conceptual model of this groundwater system in which mixing of saline and subsurface waters occurs. The different forces driving the upward flowing mixed water into the drainage axis and faults were studied in order to elucidate the springs' functioning. A comparative study of spring functioning is proposed, which clearly shows the very high sensitivity of the groundwater system to changes in recharge and discharge conditions. INDEX TERMS: 1829 Hydrology: Groundwater hydrology; 1878 Hydrology: Water/energy interactions; 1831 Hydrology: Groundwater quality; 1884 Hydrology: Water supply; KEYWORDS: coastal karst, inverse modeling, submarine spring, thermal water

Citation: Pinault, J.-L., N. Doerfliger, B. Ladouche, and M. Bakalowicz (2004), Characterizing a coastal karst aquifer using an inverse modeling approach: The saline springs of Thau, southern France, Water Resour. Res., 40, W08501, doi:10.1029/2003WR002553.

\section{Introduction}

[2] Karst systems, usually associated with carbonate rocks, are characterized by heterogeneity because of the presence of both fractures and drainage networks (the conduit network resulting from carbonate dissolution, the geological setting, and the hydraulic gradient). These systems have been intensively studied owing, in part, to the high risk of migration of contaminated groundwater in this area. Studying these systems is, however, inherently difficult owing to the difference in flow characteristics between the rock matrix and conduit systems [Baedke and Krothe, 2001; White, 1999; Larocque et al., 1998; Lakey and Krothe, 1996; Padilla et al., 1994; Dreiss, 1982, 1989; Milanovic, 1981; Kiraly, 1975]. Discharge areas of coastal karst aquifers are strongly influenced by variations in the base level, which determines the conditions of development of the conduit network. In Mediterranean regions, sea level variations during the late Tertiary and Quaternary are the major cause of changes in base level and therefore of karst development [Blanc, 1997]. Outlets along the coast can be

Copyright 2004 by the American Geophysical Union. 0043-1397/04/2003WR002553 either above or below sea level (submarine springs). The latter can be either freshwater or brackish springs and are preferential paths for seawater intrusion into the aquifer as has been reported by Potié and Ricour [1973a, 1974b] in Port Miou (France), Breznik [1973, 1998], Tadolini and Tulipano [1981], Mijatovic [1986] in the former Yugoslavia, and Arfib et al. [2000, 2001] in Crete (Almyros spring).

[3] Many of the submarine springs along the Mediterranean coast [Breznik, 1973; Paloc and Potié, 1974; Gilli, 1999] were inland when the base level was lower, that is, during the Messinian regression when the sea level dropped 1000 to $1500 \mathrm{~m}$ [Clauzon, 1990]. There are four types of submarine springs [Arfib, 2001]: (1) springs enabling saltwater intrusion into submarine conduits because of the Venturi effect, (2) springs discharging freshwater to the sea when the head is high in karst conduits, (3) springs presenting density stratification between freshwater and seawater in large submarine karst conduits (e.g., Port Miou spring, Cassis) [Potié and Ricour, 1973a, 1973b], and (4) submarine springs allowing occasional seawater intrusion depending on the hydraulic head in the aquifer and in the sea (possible tidal influence) [Drogue and Bidaux, 1986]. The Thau karst system belongs to the fourth type that is called an "inversac" in French [Gèze, 1973, 1987]. 


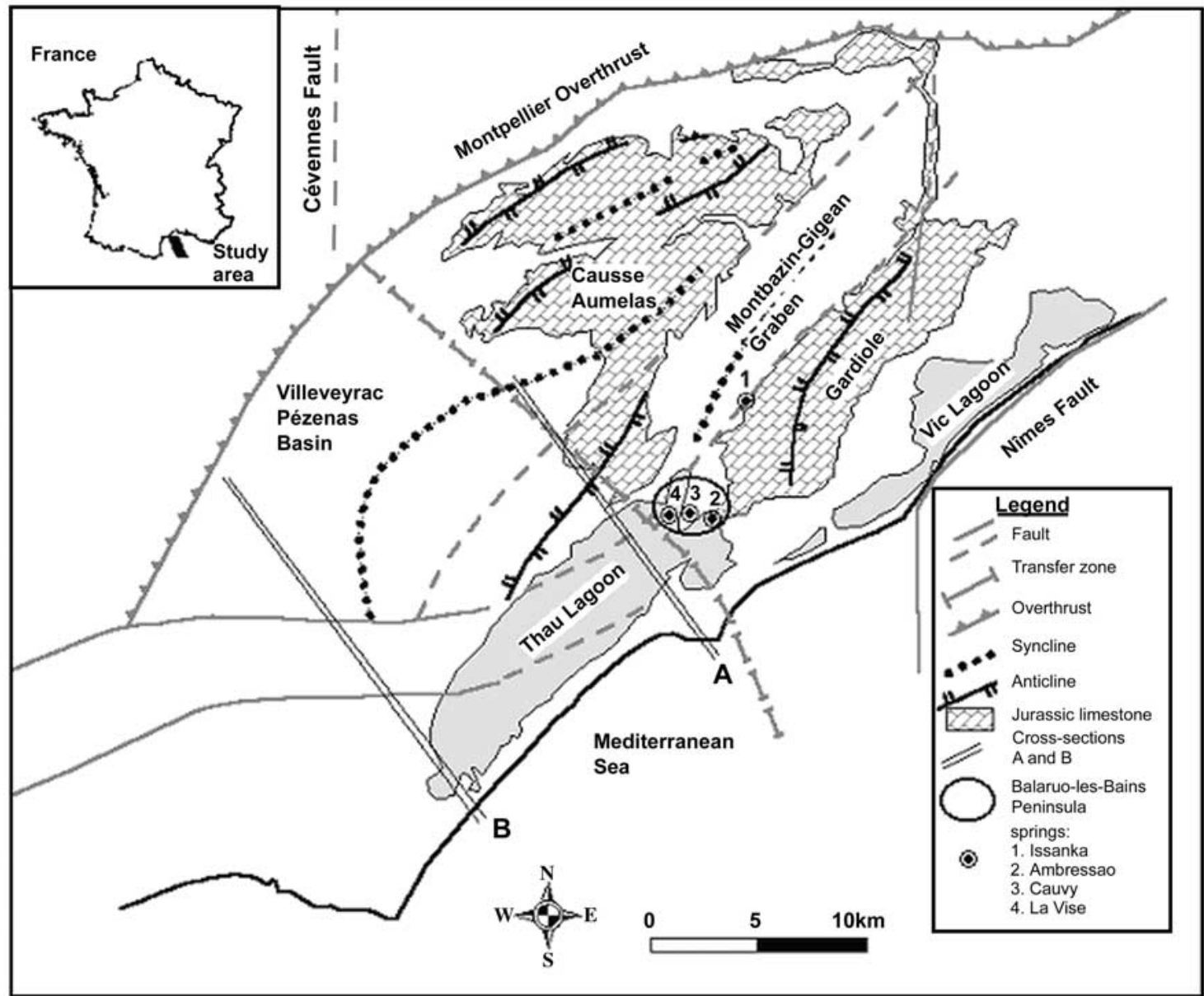

Figure 1. Structural and geological setting of the study area (modified after Aquilina et al. [2002a, $2002 \mathrm{~b}]$ ) with the major tectonic features, such as syncline and anticline axis, overthrust and fault, and karstic spring localization and cross-section traces.

[4] Thermal fluids also play a role in the Thau karst system. Low-enthalpy geothermal systems can exist in places where there is no current volcanic activity, such as in the French Massif Central [Michard and Rockens, 1983] and near mountain ranges [Vuataz, 1983; Krimissa et al., 1995; Aquilina et al., 2002]. Judging by the development of deep karstic networks and the presence of tectonic accidents due to the proximity of mountain ranges, water emerging from the outlets of coastal karst aquifers in the Mediterranean influenced by Pyrenean tectonics is probably a mixture of shallow and deep groundwater flow (local and regional flow), that is, freshwater, marine water, and thermal fluids as found in the Thau coastal karstic system. This karst system is of major economical importance since it supplies water for fish breeding, for the spa in Balaruc-les-Bains, and for the local drinking water supply. In 1993 the water quality in the thermal springs supplying the Balaruc spa was affected by very low water stages and human intervention on the submarine La Vise spring in the Thau lagoon. A usage conflict arose, and specialists were called in to determine the cause of perturbations. Geological, hydrological, and hydrochemical studies were carried out, and the chemical characterization of the saline fluids at the spa and within the karst aquifer gave some indication of the conceptual model of this limestone aquifer: the origin of saline fluids, the submarine spring, and flow pathways [Aquilina et al., 2002, 2003].

[5] On the basis of specific literature the coastal karst aquifer is characterized by using both hydrogeochemical and isotopical data [Brondi et al., 1973, 1983; Aquilina et al., 2002, 2003] and physical time series such as temperature logs. These approaches are used in order to define the conceptual model of groundwater flow (type of reservoirs and depth) as well as to consider the geometry of the saltwater intrusion zone within the aquifer [Tulipano and Fidelibus, 2002].

[6] Inverse modeling of flow and temperature and conductivity fluxes measured at the karst system's outlets or water points (springs or thermal boreholes) was performed to characterize the functioning of the system and to identify the relative contributions of freshwater, seawater, and deep thermal water. This original method is based on combining impulse responses of flow and fluxes to separate hydrographs [Pinault et al., 2001a, 2001b].

[7] This paper presents the methodological approach using inverse modeling to characterize the functioning of the deep and shallow reservoirs (1) to explain salinity, temperature, and hydraulic head variations in submarine and inland springs and boreholes and (2) to improve and to 


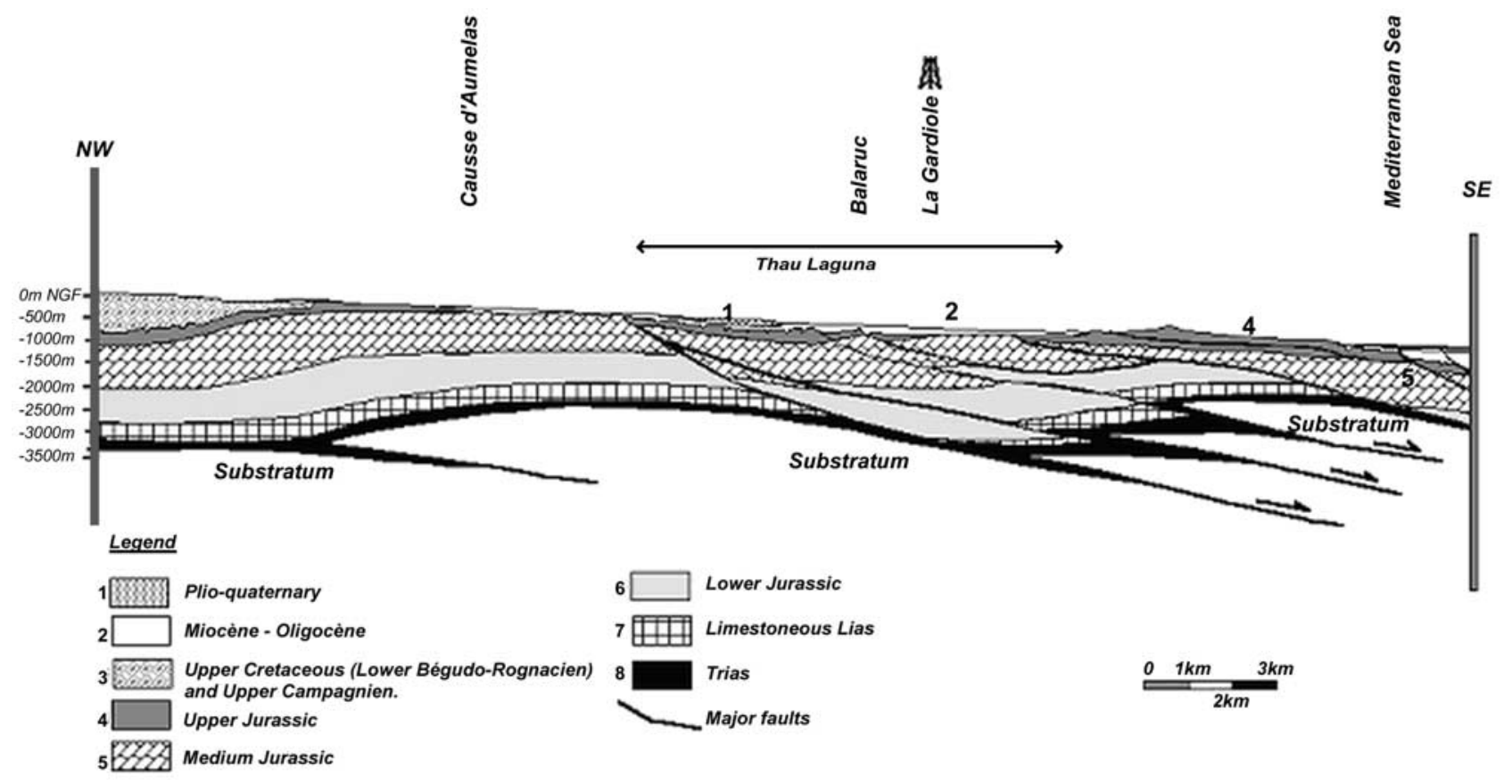

Figure 2. Regional geology across the Thau karst system: northern cross section A.

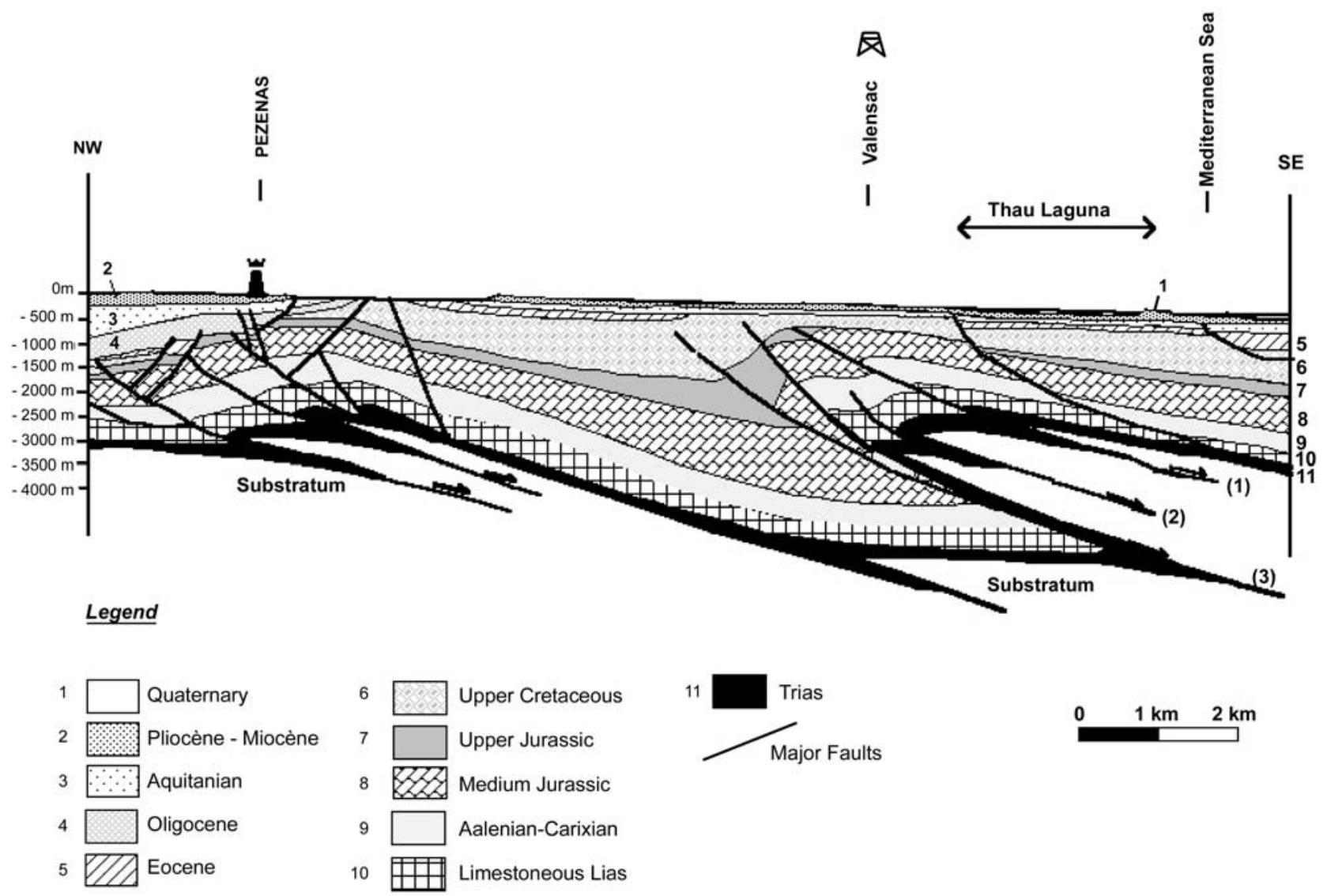

Figure 3. Regional geology across the Thau karst system: southern cross section B (Aquilina et al. [2002a, 2003]). 
quantify the conceptual model of this groundwater system in which water flows through different types of reservoirs. This approach is based on studies carried out to formulate and solve inverse models [Tikhonov and Arsenine, 1976; Morozov, 1984; Tikhonov and Goncharsky, 1987; Dietrich and Chapman, 1993; McLaughlin and Townley, 1996; Pinault et al., 2001a, 2001b].

\section{Geological and Hydrogeological Setting}

\subsection{Geological Setting}

\subsubsection{Structural Framework}

[8] The study area is located in southern France, west of Montpellier (Figure 1). The geometrical and structural model of the carbonate aquifer formations making up the Thau karstic system is characterized by a system of ramps and steps affecting the entire sedimentary series as well as by series of faults and thrusts influenced by Pyrenean chain setting up [Arthaud and Séguret, 1981] (Figures 2 and 3). This complex geological structure is the result of three major tectonic phases [Aquilina et al., 2002], the Hercynian range, the Pyrenean uplift, and the opening of the Gulf of Lion [Choukroune, 1976; Guennoc et al., 1994; Séranne et al., 1995; Séranne, 1999]. There are two major regional faults in the area, inherited from the Hercynian range: the Cévennes Fault in the NW and the Nîmes Fault in the SE (Figure 1). The depth of the carbonate basin basement, made up of Paleozoic metamorphic formations, increases from the NE to the SW. Under the NE end of the Thau lagoon (Balaruc peninsula) it is about $1500 \mathrm{~m}$ deep (1582 $\mathrm{m}$ in the Gardiole well) (Figure 3). This abrupt drop is known as the "Sète transform margin" [Séranne et al., 1995; Bénédicto et al., 1996; Séranne, 1999], the surface manifestation of which extends under the Thau lagoon, near the Balaruc peninsula (Figure 1). At the end of the Eocene the regional stress conditions changed, and the Cévennes Fault underwent strike-slip displacement [Séranne et al., 1995; Séranne, 1999]. During the Oligocene and the end of the Tertiary, there was an extensional phase that led to the generalized opening of the Gulf of Lion and the creation of the oceanic crust. During this period the compressive Pyrenean faults were reactivated as normal faults [Bénédicto et al., 1996; Séranne, 1999]: formation of the Montbazin-Gigean basin, in which Miocene formations more than $200 \mathrm{~m}$ thick lie directly over the Jurassic limestone.

\subsubsection{Geological Formations}

[9] The geological units comprise a succession of layers between the metamorphic basement with Cévennes shales, phyllites, and micaschist under the Gardiole Massif [Arthaud and Séguret, 1981; Bénédicto et al., 1996] and the sedimentary deposits at the surface. The sedimentary layers are Triassic sandstone and evaporite formations (200 $\mathrm{m}$ thick on average) that acted as the major decollement level during Pyrenean compression, Jurassic limestone that forms the backbone of the study area, and Tertiary molasse in the Montbazin-Gigean basin.

[10] Jurassic limestone crops out as two karstified massifs, the Causse d'Aumelas and the Gardiole Mountain. The Causse d'Aumelas has a tabular structure in outcrop that plunges to the southeast, the Villeveyrac-Pézenas basin, in a synclinal depression (Figure 3). The Gardiole Mountain is an anticline of Jurassic limestone that, to the west, changes into a tight fold that markedly overthrusts the Villeveyrac-Pézenas basin. The Gardiole Mountain and Causse d'Aumelas units are both bounded by thrust structures [Aquilina et al., 2003] (Figure 2).

\subsection{Hydrogeological Setting}

[11] The Thau karst system is a hydrological entity that has been delimited with geological data (structure and lithology), tracer tests, and the water budget. It is part of the aquifer system of the northern Montpellier fold (Figure 4). It has a recharge area of about $200 \mathrm{~km}^{2}$. This catchment area is oriented north-south. Recent tracer experiments and hydrogeological studies have shown a general groundwater flow direction from north to south, from the Causse d'Aumelas to the sea [Ladouche et al., 2001]. Although flow directions can be locally more complex because of the heterogeneity of the karst aquifer, this general north-south flow is also found in the Gardiole Massif [Dubois, 1964; Bonnet and Paloc, 1969; Auriol et al., 1988]. An artificial tracer test between La Vène and Issanka springs showed that the two massifs are hydrologically connected [Ladouche et al., 2001]. As a result of this complex geological structure, the major outlets of the Thau karstic system are located near the Balaruc peninsula, where water from three different types of reservoirs converges: surface water (freshwater and seawater), karst groundwater, and thermal fluids [Aquilina et al., 2002].

[12] The Thau karst system is considered a coastal system because one of its outlets, La Vise spring, is located $30 \mathrm{~m}$ below sea level in the Thau lagoon. The principal springs are located either along a major fault (Issanka spring and La Vise spring) or close to it (Cauvy and Ambressa springs) or on the SE edge of Gardiole Mountain (La Robine de Vic spring) (Figure 1). During high-water stages an overflow spring, La Vène spring, located at the northern edge of the Montbazin-Gigean graben, is the main outlet of the karst system.

[13] The temperature of spring water varies from one spring to another between $16^{\circ} \mathrm{C}$ and $21^{\circ} \mathrm{C}$, the mean being around $17^{\circ} \mathrm{C}$. Electrical conductivity values are generally between 500 and $1700 \mu \mathrm{S} / \mathrm{cm}$ but reach $7000 \mu \mathrm{S} / \mathrm{cm}$ in $\mathrm{La}$ Robine de Vic spring. The water emerging from the limestone springs has a major thermal water component and has long been used for the spa in Balaruc-les-Bains. The temperature of the thermal water tapped by the spa's boreholes is $26^{\circ} \mathrm{C}-50^{\circ} \mathrm{C}$, with no correlation between greater depth and higher temperatures $\left(28^{\circ} \mathrm{C}\right.$ for $490 \mathrm{~m}$ and $50^{\circ} \mathrm{C}$ for $120 \mathrm{~m}$ ). The electrical conductivity of these thermal waters, 2630-21,300 $\mu \mathrm{S} / \mathrm{cm}$ [Aquilina et al., 2002], is higher than that of the spring water.

\section{Hydrogeological Monitoring}

[14] Three coastal springs, three thermal wells, and six piezometers (of a 70-piezometer network) were monitored. Most of the points were equipped with multichannel data loggers to measure the hydraulic head, temperature, and conductivity.

[15] The submarine La Vise spring required specific equipment. One of the outlets at the bottom of the cone was microcaptured with a PVC pipe, and water head as well as lagoon levels have been recorded every half hour along 


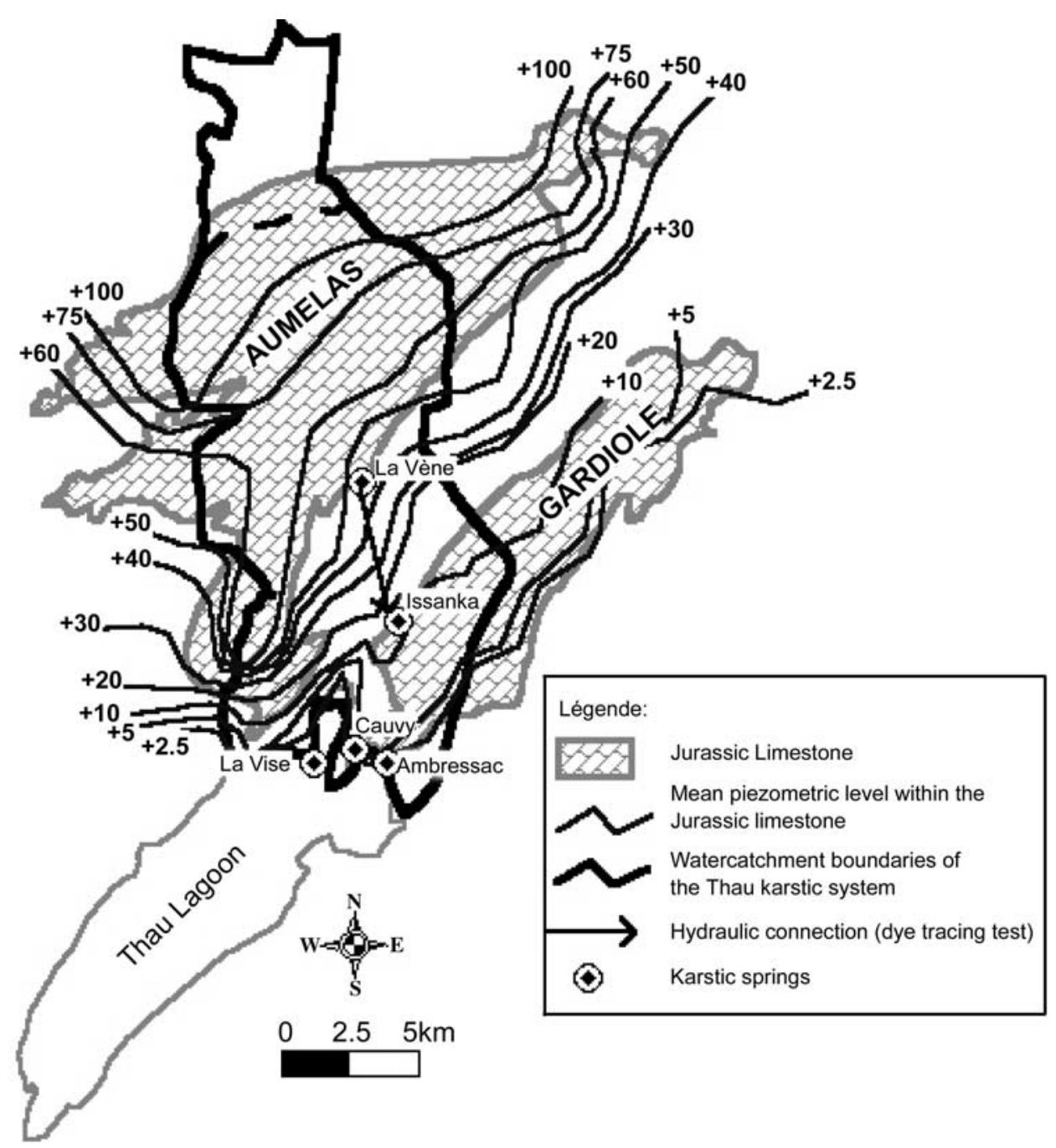

Figure 4. Hydrogeological setting of the Thau karstic system that belongs to the Jurassic limestone outcropping of the northern Montpellier fold. Major karstic springs are set up, as well as the mean regional piezometric map drawn from data of a 70-point network. Shown are the general (north-south) groundwater flow direction, the hydrogeological connection between La Vène spring and Issanka spring as well as the water catchment boundaries. The upper part of the water catchment belongs to the Coulazou River catchment (boundary with dashed line). 

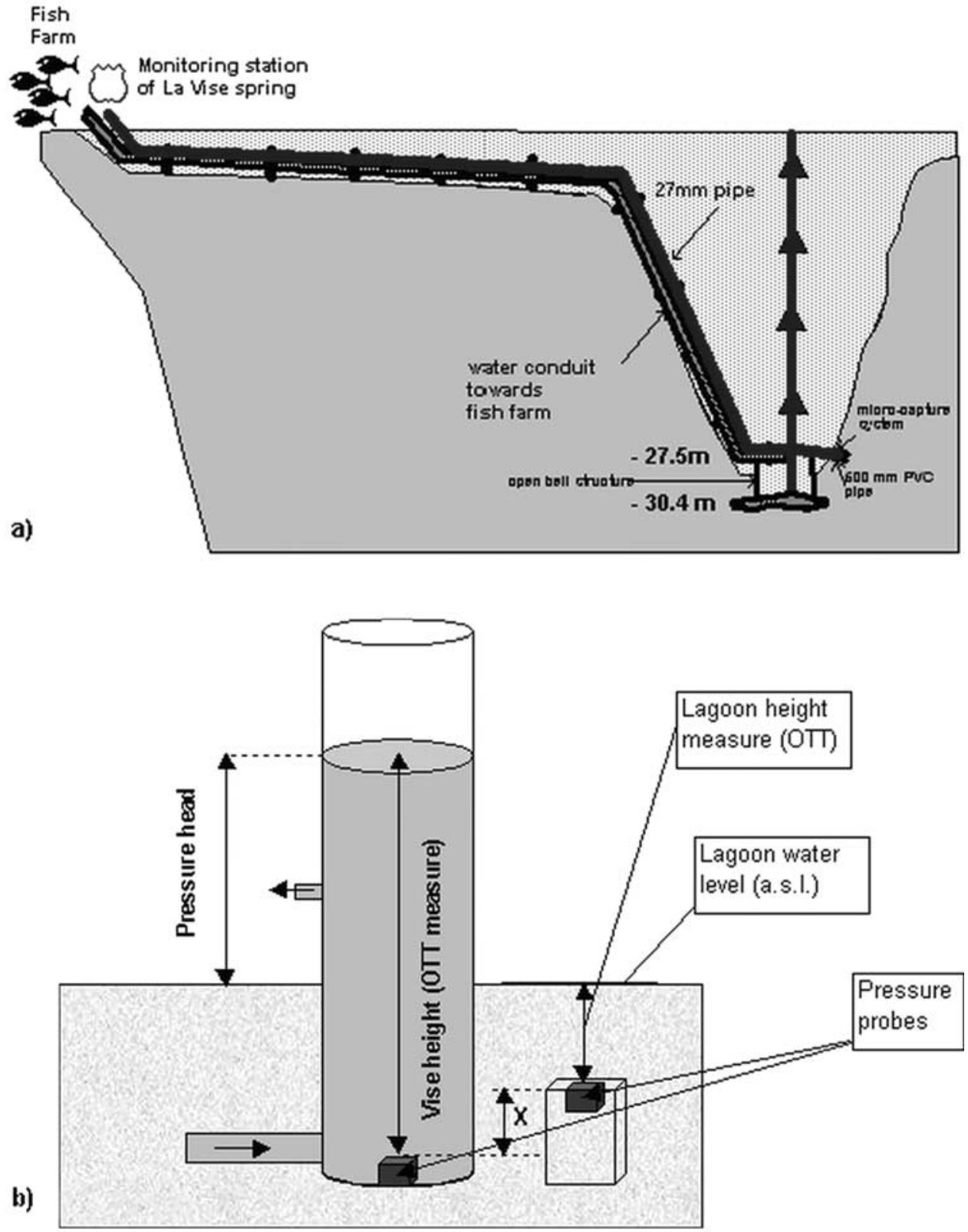

Figure 5. La Vise spring monitoring system. (a) General sketch of the microcapture system on one outlet in the lower part of the La Vise cone, whose PVC pipe is fixed on the outflow pipe used for the fish farming. (b) Detailed sketch of pressure probes used to monitor the partial head pressure of the aquifer and the lagoon level variations that, because of their density, influenced the aquifer pressure.

with conductivity, temperature, and the hydraulic head since 1998 (Figures 5a and 5b). During the 1960s a bell was placed over the main outlet at the bottom of the cone to optimize pumping for the fish farm. Fishermen took the bell off in 1993 because it increased sedimentation along the cone's sidewalls and perturbed shell growth. During our study (1998-2001, with some periods disturbed by vandalism or adjustments to the system) the bell did not cover the main outlet of La Vise spring.

\section{Conceptual Model of Groundwater Flow}

[16] Inland and submarine springs near the Thau lagoon are fed by both shallow groundwater and the water (a mixture of deep and shallow waters) rising up through the karst conduits (Figure 6). The temperature of the spring water is a marker of thermal water, whereas the conductivity is a marker of both thermal and marine waters. However, the temperature had not been monitored in the submarine La Vise spring, where physicochemical parameter determination of spring water was remote.

[17] The conductivity of the spring water increases sharply after rainfall events (Figure 7), reaching 6 and $9 \mathrm{mS} / \mathrm{cm}$ in La Vise and Ambressac springs, respectively. Such high values disclose a significant contribution of saline groundwater in spring water. Temperature of the Ambressac spring shows a peak in August before the hydraulic head increases, then it decreases drastically while conductivity increases, 


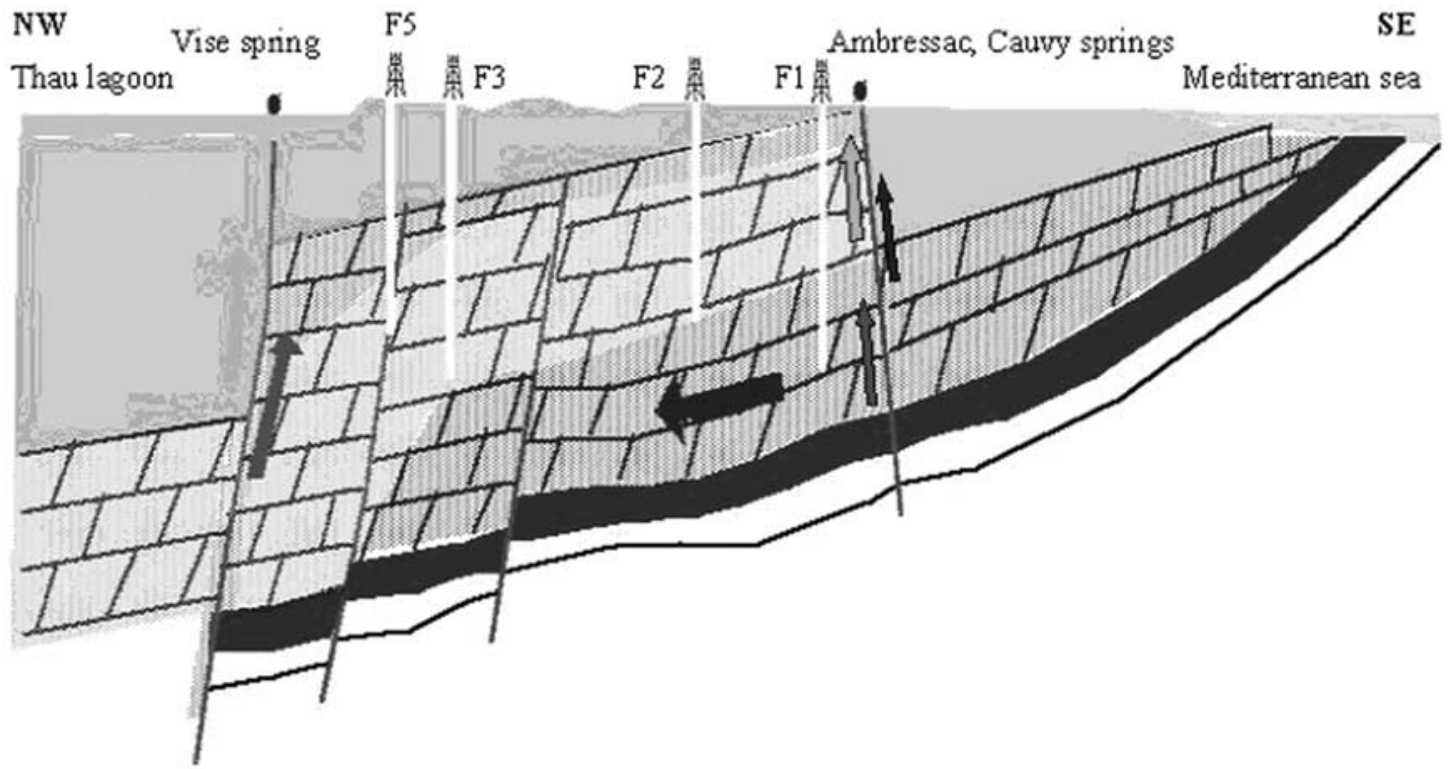

Legend

Pliocene

Upper Jurassic
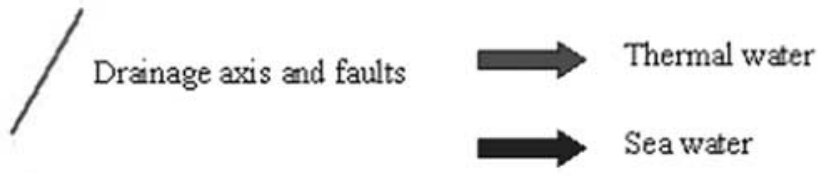

Clayey limestone $/$ Thermal well

Callovian

$\longrightarrow$ Freshwater (unmixed)

Figure 6. Schematic cross section showing groundwater flow in the Thau karst system. Some of the groundwater infiltrates deeply and acquires the signature of thermal water before rising in karst conduits because of the pressure head exerted by the infiltrating water. Confined groundwater moves upward through the karst conduits because of both the hydraulic head under high storage conditions and a density decrease of mixed water (thermal water, seawater, and freshwater) in the shallow reservoir. Unmixed freshwater or mixed water may feed the springs according to the storage conditions. The Pliocene cover is impermeable, and recharge of shallow groundwater occurs from the Causse d'Aumelas and Gardiole Mountain (Figure 3). See color version of this figure at back of this issue.
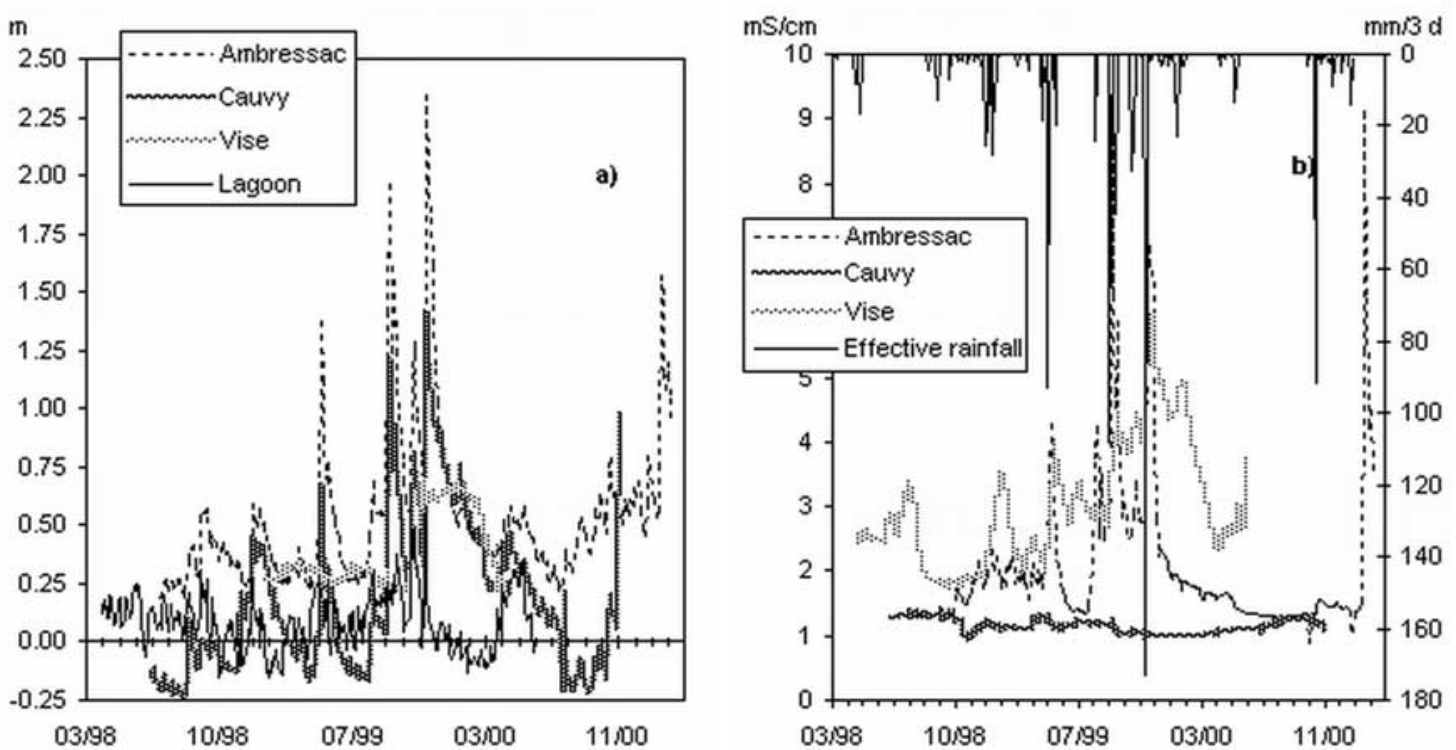

Figure 7. (a) Water level in the springs and in the lagoon. (b) Spring water conductivity and effective rainfall. 

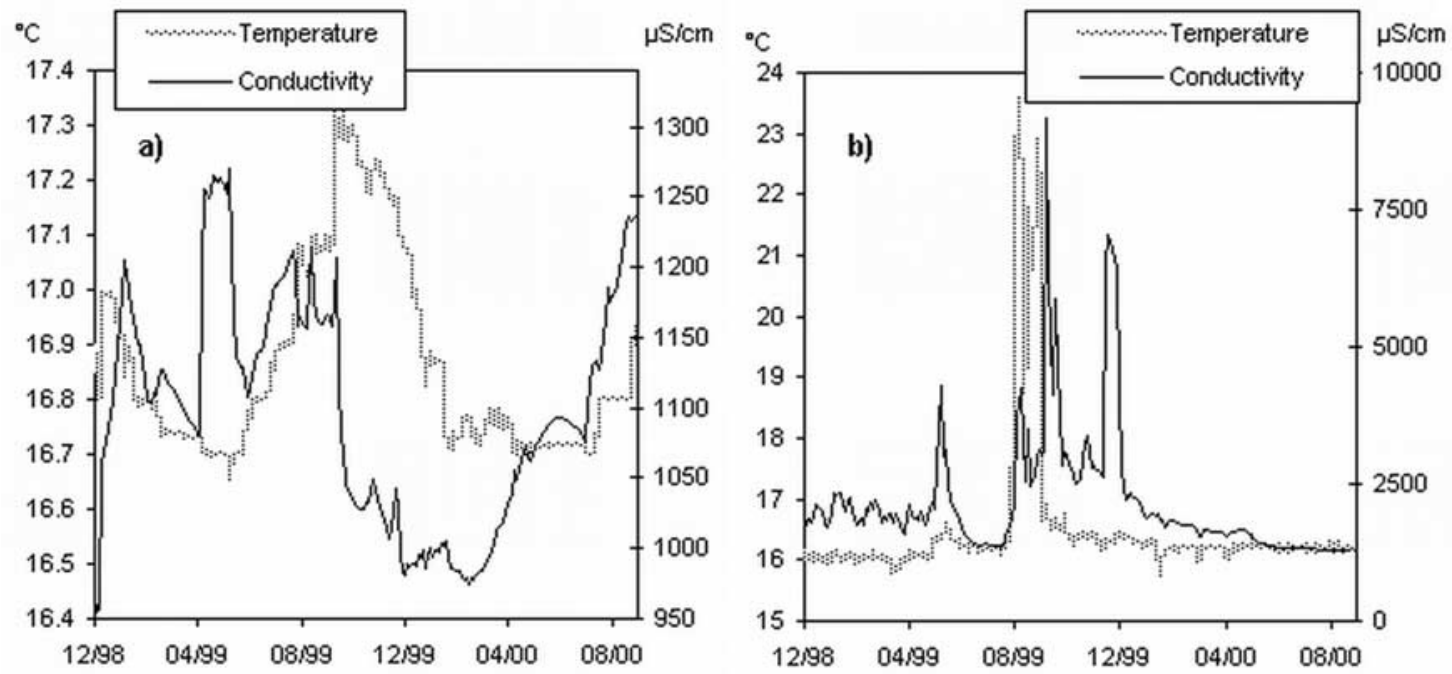

Figure 8. Monitoring of conductivity and temperature for (a) Cauvy spring (b) Ambressac spring.

which shows that saline water has mainly a marine origin (Figure 8). As for the Cauvy spring, the conductivity of the spring water anticipates the peak flows for the first part of 1998 and then decreases regularly as the hydraulic head increases, whereas the temperature follows the hydraulic head, which discloses that the saline water has a deep origin. Although temperature was not monitored in La Vise spring, the evolution of the ratio ${ }^{87} \mathrm{Sr} /{ }^{86} \mathrm{Sr}$ versus $\mathrm{Ca} / \mathrm{Sr}$ of spring water is the fingerprint of deep thermal water [Aquilina et al., 2003]. Therefore conductivity was used as a proxy for temperature for the study of this spring.

[18] Thermal water characteristics have been deduced from well F9 (Table 1) in which conductivity, temperature, and density are almost constant, the mean values being $17.2 \mathrm{mS} / \mathrm{cm}, 49.7^{\circ} \mathrm{C}$, and $1.014 \mathrm{~g} / \mathrm{cm}^{3}$, respectively (Table 1). The temperature of the deep reservoir that has been deduced from geothermometers is about $80^{\circ} \mathrm{C}-100^{\circ} \mathrm{C}$, which enables the estimation of the depth of the reservoir at about 2000-2500 $\mathrm{m}$ because the geothermal gradient is $3^{\circ} \mathrm{C} / 100 \mathrm{~m}$ [Aquilina et al., 2002].

[19] Mixing of three components, groundwater in the shallow karst aquifer, denser thermal water rising from the deep karst aquifer, and marine water, drives groundwater circulation in the rising water column. Since spring flow increases after rainfall events (Figure 7), the rising water column could be driven, after effective rainfall events, by (1) increased head in the deep reservoir, (2) increased head in the shallow confined reservoir hydraulically connected to the karst conduits, or (3) decreased water density in the rising water column when thermal water is diluted with shallow groundwater. The density of freshwater in the shallow reservoir is close to 1 , and it is therefore weakly mineralized in comparison with thermal and marine waters. Its conductivity is estimated to be around $0.8 \mathrm{mS} / \mathrm{cm}$ on the basis of data from wells tapping the shallow karst aquifer. The springs are therefore located at the convergence of thermal and marine waters rising in karst conduits where they mix with confined subsurface waters.

[20] Inverse modeling was done to separate the unmixed (freshwater in the shallow reservoir) and mixed (saline water) components in spring flow hydrographs. The char- acteristics of the unmixed component are assumed to be constant in comparison with those of the mixed component. While saline water is marked by its conductivity, there is no relevant tracer that can be easily monitored for shallow groundwater. Nevertheless, the impulse responses of the mixed and unmixed waters are very different, the former responding very rapidly to effective rainfall events, whereas the latter is much delayed.

[21] By using the conductivity or the temperature of the mixed water, we can determine the mechanisms responsible for groundwater circulation when it is associated with the analysis of impulse responses as the lag increases. Indeed, the proportions of shallow groundwater and saline water versus time in the karst conduits is variable, and the response differs significantly from one spring to another, which, provided we have accurately separated mixed and unmixed water hydrographs, can be used to indicate the force driving groundwater circulation.

\section{Mathematical Modeling and Numerical Analysis}

[22] Data processing was done using the TEMPO code [Pinault, 2001]. The inverse model uses rainfall and hydraulic head or rainfall and flux data to calculate unit hydrographs and impulse responses of fluxes and thereby to separate hydrographs (Figure 9). Fluxes are defined as the product of hydraulic head (in relation to a reference level) and water conductivity or water temperature (in relation to a reference value). In order to keep the dimension of the pressure head expressed in meters, the calculation of fluxes

Table 1. Physical Parameters of the Thermal Water Sampled From Well F9

\begin{tabular}{lccc}
\hline Sampling Date & Temperature, ${ }^{\circ} \mathrm{C}$ & Conductivity, $\mathrm{mS} / \mathrm{cm}$ & Density \\
\hline 31 July 1996 & 49.9 & 17.18 & 1.01388 \\
3 June 1997 & 50.3 & 16.87 & 1.01349 \\
2 Feb. 2000 & 48.9 & 17.60 & 1.01425 \\
\hline
\end{tabular}




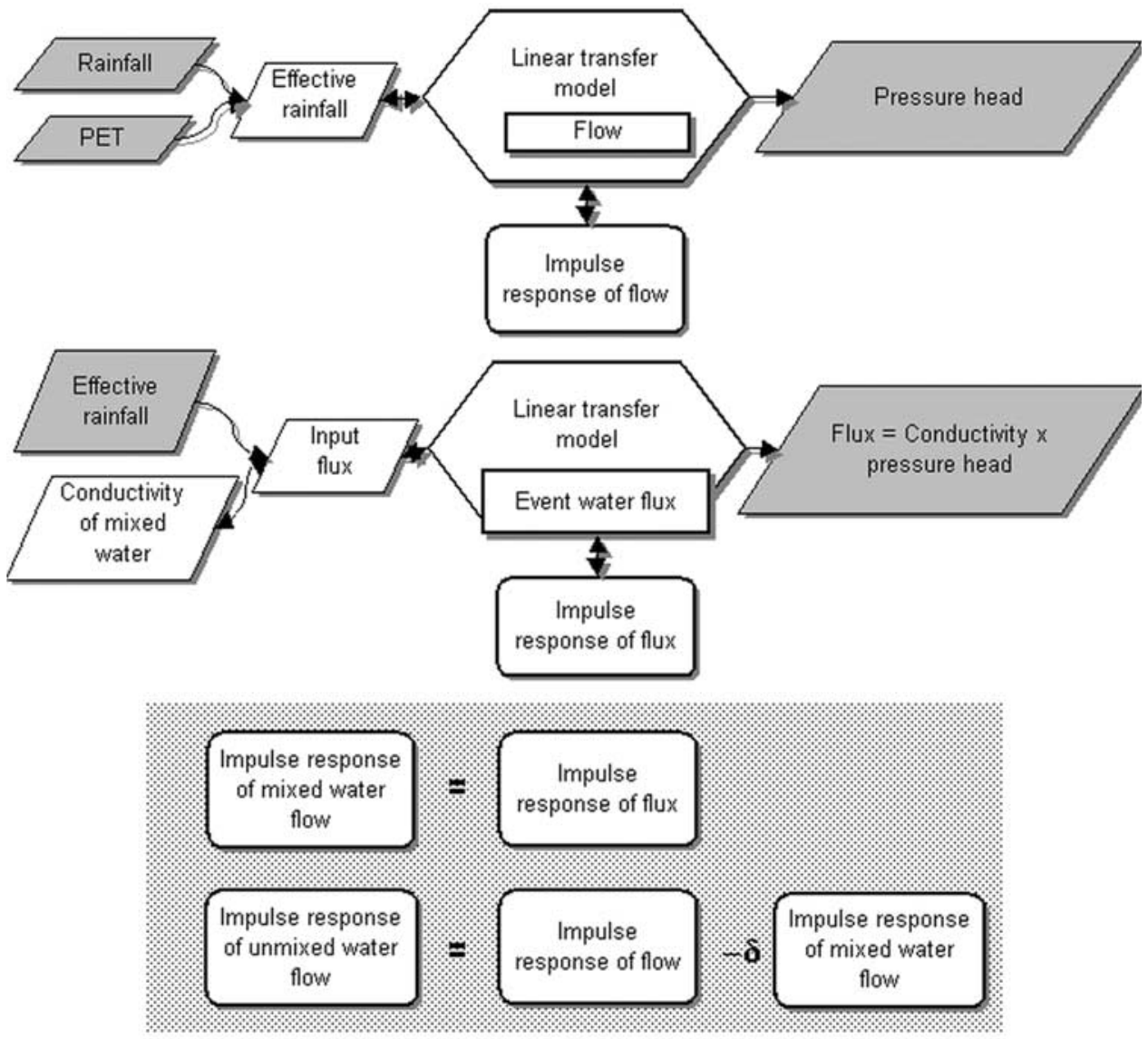

Figure 9. Schema of hydrograph separation. Variables in gray boxes are known. Pressure head is expressed in relation to the base water level. The water conductivity of mixed water is expressed in relation to the water conductivity of unmixed water, $0.8 \mathrm{mS} / \mathrm{cm}$. The impulse response of mixed water flow is the impulse response of flux since conductivity is used as the tracer of mixed water in the shallow reservoir. The impulse response of unmixed water flow is deduced from impulse responses of flow and flux.

is carried out so that the conductivity or the temperature values are divided by their mean value.

[23] As opposed to what hydrologists have been doing for years, we used impulse responses in their entirety and were therefore able to accurately separate hydrographs. Since this new approach requires that impulse responses related to flow and fluxes, as well as the mixing processes occurring into the karst conduits, be calculated accurately, new concepts had to be developed [Pinault et al., 2001a, 2001b].

[24] The hydraulic head $\Delta H\left(t_{i}\right)$, measured in piezometers and expressed in relation to a reference level, is the result of (1) rainwater infiltration, both rapid and delayed; (2) discharge from the shallow confined aquifer; and (3) discharge from the saline water reservoirs. This can be written as

$$
\Delta H=1 / \eta \Gamma * R_{\mathrm{eff}},
$$

where the asterisk represents the discrete convolution product, $R_{\text {eff }}$ is the effective rainfall, $\Gamma$ is the normalized impulse response of the hydraulic head $\Delta H\left(t_{i}\right)$ to effective rainfall, and $\eta$ is a constant related to the effective porosity $\omega_{e}$ in the shallow reservoir: $\omega_{e}=\eta / \max \left[\Gamma\left(t_{i}\right)\right]$. After averaging the two members of equation (1), the following constraint for water mass conservation is obtained:

$$
\overline{\Delta H}=1 / \eta \bar{R}_{\text {eff }}=\gamma / \eta \bar{R},
$$

where $\gamma$ is the proportion of rainwater lost by evapotranspiration, that is, the mean contribution of rainfall to effective rainfall.

[25] The effective rainfall $R_{\text {eff }}\left(t_{i}\right)$ is calculated from the rainfall $R\left(t_{i}\right)$ and the effective rainfall threshold $\Omega\left(t_{i}\right)$ such that

$$
R_{\text {eff }}\left(t_{i}\right)= \begin{cases}R\left(t_{i}\right)-\Omega\left(t_{i}\right) & R\left(t_{i}\right) \geq \Omega\left(t_{i}\right) \\ 0 & R\left(t_{i}\right)<\Omega\left(t_{i}\right) .\end{cases}
$$

Here $\Omega$ can be interpreted as the available soil storage deficit related to both rainfall and potential evapotranspiration such that

$$
\Omega=\left[\Gamma_{\Omega, \mathrm{PET}} * \mathrm{PET}+\Gamma_{\Omega, \mathrm{R}} * R+C^{s t}\right]
$$

where $\Gamma_{\Omega, \mathrm{PET}}$ and $\Gamma_{\Omega, R}$ are impulse responses of $\Omega$ to potential evapotranspiration (PET) and to rainfall $R$, 
Table 2. Observation Periods for the Different Springs

\begin{tabular}{llc}
\hline \multicolumn{1}{c}{ Spring } & Observation Period & Duration, years \\
\hline Ambressac & July 1998 to Dec. 2000 & 2.46 \\
La Vise & Jan. 1999 to April 2000 & 1.24 \\
Cauvy & June 1998 to Sept. 2000 & 2.28 \\
\hline
\end{tabular}

respectively. These impulse responses are represented by trapezoids with four degrees of freedom, with $\Gamma_{\Omega, \text { PET }}$ being positive and $\Gamma_{\Omega, R}$ being negative; rainfall causes a decrease in $\Omega\left(t_{i}\right)$, whereas potential evapotranspiration causes an increase in $\Omega\left(t_{i}\right)$ [Pinault et al., 2001a]. The inverse method attempts to calculate the impulse responses $\Gamma, \Gamma_{\Omega, \mathrm{PET}}$, and $\Gamma_{\Omega, R}$ and the constant $C^{s t}$.

[26] Another aspect of inverse modeling concerns conductivity and thermal fluxes, that is, the product of the hydraulic head $\Delta H\left(t_{i}\right)$ and conductivity (or temperature) expressed relative to a reference value. Spring water conductivity varies with time because of the mixing of thermal, marine, and shallow groundwaters. These fluxes are therefore used to characterize saline water, and, consequently, the reference value for conductivity or temperature is that of freshwater in the shallow reservoir.

[27] Hydrograph separation is done using freshwater in the shallow karstic groundwater and the mixture of saline and shallow groundwater rising in the karst conduits (Figure 6). The flux $F\left(t_{i}\right)$ can be written as a piezometric level of groundwater whose conductivity is $\overline{\Delta \mu}$ :

$$
\begin{aligned}
F\left(t_{i}\right) & =\left[\Delta H\left(t_{i}\right)\right]\left[\Delta \mu\left(t_{i}\right) / \overline{\Delta \mu}\right] \\
& =1 / \eta\left\{\Gamma_{\text {flux }}\left(t_{i}\right) *\left[R_{\text {eff }}\left(t_{i}\right) \Delta \beta\left(t_{i}\right) / \overline{\Delta \mu}\right]\right\},
\end{aligned}
$$

where $\Delta \mu\left(t_{i}\right)$ is the conductivity (or temperature) measured in piezometers and $\Gamma_{\text {flux }}$ is again a normalized impulse response. In this way the following relationship holds:

$$
\bar{F}=\overline{\Delta H}=1 / \eta \bar{R}_{\mathrm{eff}},
$$

according to equation (2). The term $\left[1 / \eta R_{\text {eff }}\left(t_{i}\right)\right]\left[\Delta \beta\left(t_{i}\right) / \overline{\Delta \mu}\right]$ is the input flux of mixed water, and $\Delta \beta\left(t_{i}\right) / \Delta \mu$ is a calculated function of time, which represents the relative variations of the conductivity (or temperature) of mixed water in the reservoir

[28] To solve equation (5) relative to mass transfer, we need a model for the mixed water conductivity (or temperature) $\Delta \beta\left(t_{i}\right)$ in the shallow aquifer, which may be represented by its trigonometric series, whose Fourier coefficients are $\hat{c}_{n}, n=0, N$, because of their pseudoperiodic behavior from year to year. Thus the resolution of equation (5) amounts to the estimation of the set of functions $\left(\Gamma_{\text {flux }}, \hat{c}\right)$. One cycle a year is used in Fourier transforms; that is, $N$ is the number of years in the observation period.

\section{General Analysis of Results and Discussion}

[29] The raw data were aggregated to create a continuous 3-day sampling period, which is in agreement with both calculation requirements and the relaxation time for this particular karst system (Figure 7 and Table 2).

\subsection{Ambressac Spring}

[30] Figures $10 \mathrm{~b}$ and $10 \mathrm{~d}$ represent the models of the piezometric level and flux $F\left(t_{i}\right)=\left[\Delta H\left(t_{i}\right)\right]\left[\Delta \mu\left(t_{i}\right) / \overline{\Delta \mu}\right]$ that result from the procedures outlined in Figure 9 (the conductivity reference value being $0.8 \mathrm{mS} / \mathrm{cm}$ ). The available storage deficit $\Omega$ (Figure 10a) is such that $\bar{R}_{\text {eff }}=0.61 \bar{R}$, where $\bar{R}$ is the mean rainfall. Under such conditions the available water stored in the soil is zero in winter when the soil is saturated (Figure 10a). The trigonometric series of mixed water conductivity is shown in Figure 10c. The effective porosity $\omega_{e}$ calculated with equation (2) is $9.6 \%$.

[31] In Figure 10e the unit hydrograph is plotted alongside the weighted transfer functions of mixed and unmixed waters. In a general formulation, unit hydrograph separation requires both event water and pre-event water tracers. The event water tracer increases after a rainfall event, whereas the pre-event water tracer decreases [Pinault et al., 2001a, 2001b]. Here the only tracer we have is the conductivity of spring water due to intrusion of seawater, which can be used to trace the event water since there is a positive anomaly in spring water conductivity after an effective rainfall event (Figure 7). Although we have no specific tracer for the unmixed water, the components can be accurately separated because the impulse response for the unmixed water is much more delayed than that of the mixed water in the karst conduits, which is driven mainly by a piston flow effect. The transfer function of unmixed water $\Gamma_{\text {unmixed }}$ is deduced from the unit hydrograph $\Gamma$ and the transfer function of mixed water $\Gamma_{\text {mixed }}$ so that

$\Gamma_{\text {unmixed }}=\Gamma-\max (\delta) \Gamma_{\text {mixed }}$

$0 \leq \delta \leq 1, \quad \Gamma_{\text {unmixed }}\left(t_{i}\right) \geq 0, \quad t_{i}=0, \Delta t, 2 \Delta t, \cdots, i \Delta t, \cdots$,

where $\Delta t$ is the sampling rate ( 3 days). This hypothesis is supported by the strong similitude of the first part of the unit hydrograph and the transfer function of mixed water marked by its conductivity (Figure 10e), showing that the transfer function of unmixed water increases slowly after a rainfall event, then remains steady as the lag increases. The unmixed water impulse response is therefore the part of the unit hydrograph that remains after the mixed water contribution has been subtracted. Equation (6) gives $\Gamma_{\text {unmixed }}=\Gamma-0.30 \Gamma_{\text {mixed }}$. Thus the unmixed water component shows what could represent a steady state as the lag increases (Figure 10e), the erratic shape of the impulse response resulting from the shortness of the observation period in comparison with the length of the unit hydrograph. Mixed water conductivity (Figure 10c) is $\overline{\Delta \mu}$ $\Delta \beta\left(t_{i}\right) / 0.30+0.8 \mathrm{mS} / \mathrm{cm}$ (the reference value being $0.8 \mathrm{mS} / \mathrm{cm}$ ). The response of the mixed water reservoir is rapid, judging from the variability of water conductivity when effective rainfall events occur (Figure 10c). When there is no significant effective rainfall event, saline water inundates the mixed water reservoir. About $14 \%$ of the mixed component was pure seawater at the end of summer 1999 (conductivity was $8 \mathrm{mS} / \mathrm{cm}$, whereas conductivity of seawater was $57 \mathrm{mS} / \mathrm{cm}$ ). Effective rainfall events that 

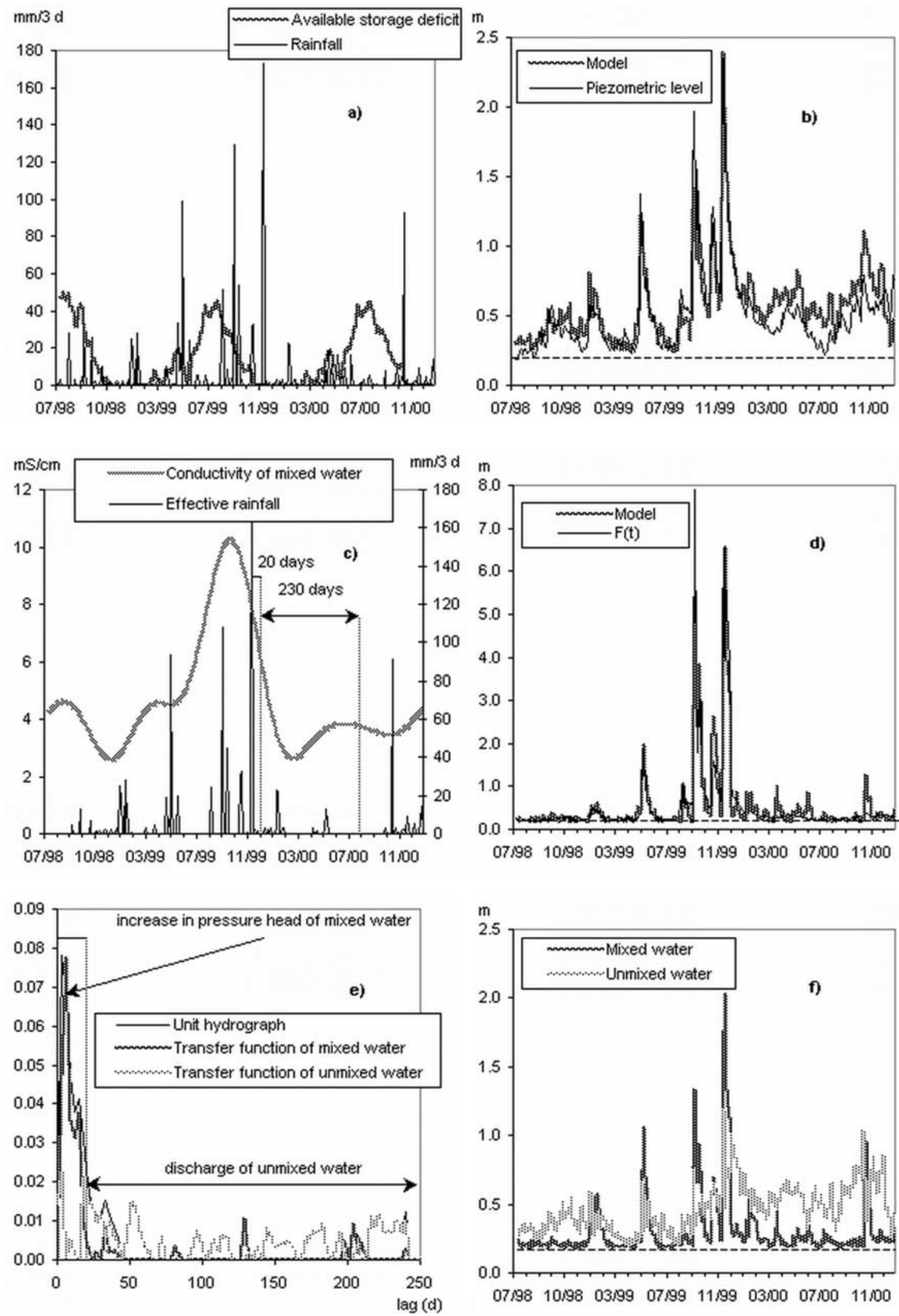

Figure 10 


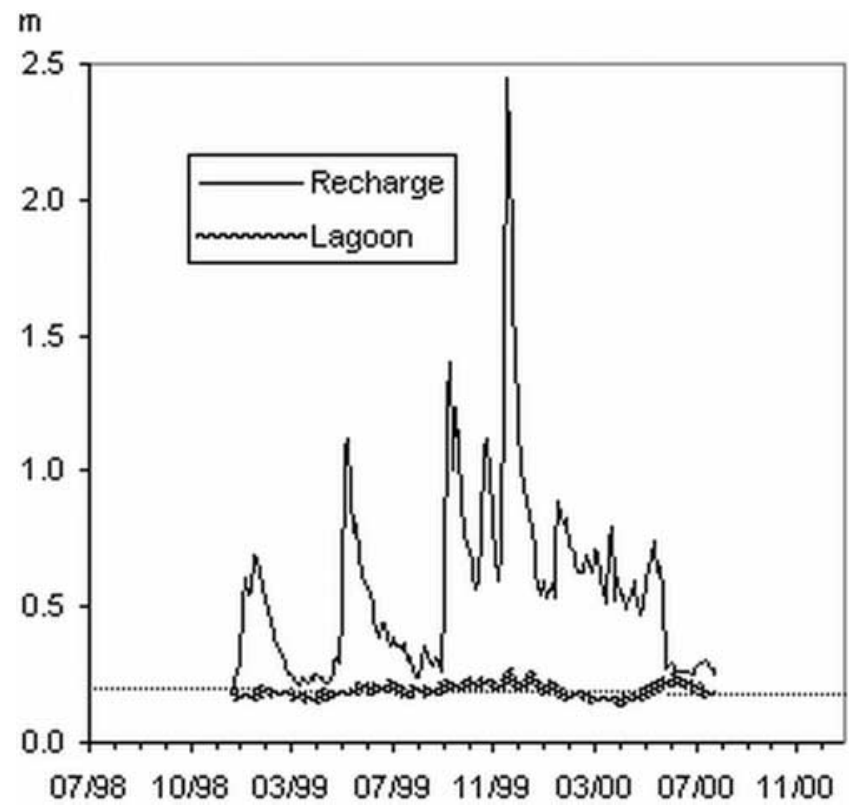

Figure 11. The two components of the piezometric level of Ambressac spring when the water level in the lagoon is considered to be an input in the model. The reference level is represented by the dotted line $(0.2 \mathrm{~m})$.

occurred that year on 2 September and 12-13 November recharged the reservoir with shallow groundwater, and the conductivity subsequently decreased from 10 to $3 \mathrm{mS} / \mathrm{cm}$.

[32] Following an increase in the hydraulic head in the confined aquifer, the impulse response of the mixed water is very short and vanishes 20 days after a rainfall event (Figure 10e). The initial pulse of the unit hydrograph is caused by the increase in the head in the shallow confined aquifer in which mixed water is diluted (Figure 10c). This shallow aquifer is connected to the karst conduits, owing to the decrease in mixed water conductivity after rainfall events. More than 20 days after a rainfall event, the Ambressac spring is fed mainly by the shallow unmixed groundwater since the contribution of the mixed water transfer function in the unit hydrograph is very low. The main force driving the saline water upward is the increase in the head of the confined groundwater. The impulse response of the mixed water is very short. The emergence of mixed water from the spring ceases as soon as the head in the confined aquifer drops below the level of the spring (Figure 10f). The spring is then fed by unmixed groundwater for about
400 days. Only the first 250 days are represented in Figure 10e.

[33] To verify that the Ambressac spring is not influenced by the level of the Thau lagoon, equation (1) was rewritten so that the Ambressac piezometric level $\Delta H\left(t_{i}\right)$ is split into two components, one related to recharge and the other to water level variations in the lagoon $\Delta H_{\text {lagoon, }}$

$$
\Delta H=1 / \eta\left[\lambda \Gamma * R_{\text {eff }}+\lambda_{\text {lagoon }} \Gamma_{\text {lagoon }} * \Delta H_{\text {lagoon }}\right],
$$

where $\lambda$ and $\lambda_{\text {lagoon }}$ are positive factors such as $\lambda+\lambda_{\text {lagoon }}$. $\left|\overline{\Delta H_{\text {lagoon }}}\right| / \bar{R}_{\text {eff }}=1$. $\Gamma_{\text {lagoon }}$ is the normalized transfer function between the lagoon and the Ambressac spring (from the lagoon to the piezometer if $\Delta H_{\text {lagoon }}\left(t_{i}\right)>0$ or from the piezometer to the lagoon if $\left.\Delta H_{\text {lagoon }}\left(t_{i}\right)<0\right)$. The two terms $(1 / \eta) \lambda \Gamma^{*} R_{\text {eff }}$ and $(1 / \eta) \lambda_{\text {lagoon }} \Gamma_{\text {lagoon }} * \Delta H_{\text {lagoon }}$ are plotted in Figure 11. They show that the contribution of the lagoon is very small and can be disregarded. This is also true for the other springs.

\subsection{La Vise Spring}

[34] The hydraulic head and saline water flux data calculated from water spring conductivity were processed as for the Ambressac spring (Figure 12). The reference level for the hydraulic head is $0.20 \mathrm{~m}$, and for conductivity it is $0.8 \mathrm{mS} / \mathrm{cm}$, the same as for the Ambressac spring. There is only a very small proportion of unmixed water in the unit hydrograph, which is very similar to the transfer function of the mixed water (Figure 12e). Equation (6) leads to $\Gamma_{\text {unmixed }}=\Gamma-0.88 \Gamma_{\text {mixed }}$. Water conductivity in the mixed water reservoir (Figure 12c) is similar to that of the Ambressac spring, although saline water has now a deep origin, the reservoir being inundated by thermal water until effective rainfall events decrease the conductivity. An increase in the hydraulic head in the karst conduits is here, again, triggered by the increase in the head in the shallow confined aquifer but, as opposed to what occurred in the Ambressac spring, thermal water flow to the spring is sustained beyond the piston flow effect. It increases for 50 days after the rainfall event, which suggests that the driving force here is the lower density of the mixed water. The density decreases as the thermal water becomes increasingly diluted by the shallow groundwater in the rising column.

[35] La Vise spring is always fed with mixed water, the proportion of unmixed water in the unit hydrograph being very low (12\%, Figure $12 \mathrm{f})$. The depth of the mixed water reservoir can be estimated if we assume that the increase in the unit hydrograph beyond 50 days after a rainfall event

Figure 10. Data for Ambressac spring. (a) Available storage deficit $\Omega$, that is, the available water reserves in soils and vegetation, and rainfall $\bar{R}_{\mathrm{eff}}=0.61 \bar{R}$. (b) Comparison of the piezometric level and the model $(\mathrm{Nash}=78 \%)$. The reference level is $0.19 \mathrm{~m}$. (c) Trigonometric series representing the mixed water conductivity and effective rainfall. The reference value for conductivity is $0.8 \mathrm{mS} / \mathrm{cm}$. The delays corresponding to the alteration of the unit hydrograph behavior are represented after the rainfall events that occurred in November 1999: increase in the pressure head of mixed water and discharge of unmixed water. (d) Comparison of the flux $F\left(t_{i}\right)$ and the model (Nash $=89 \%$ ). (e) Unit hydrograph and weighted transfer functions. The transfer function of unmixed water is deduced from the unit hydrograph and the transfer function of mixed water. The weights associated with the transfer functions of mixed and unmixed waters are 0.3 and 0.7 , respectively. (f) Hydrograph separation. 

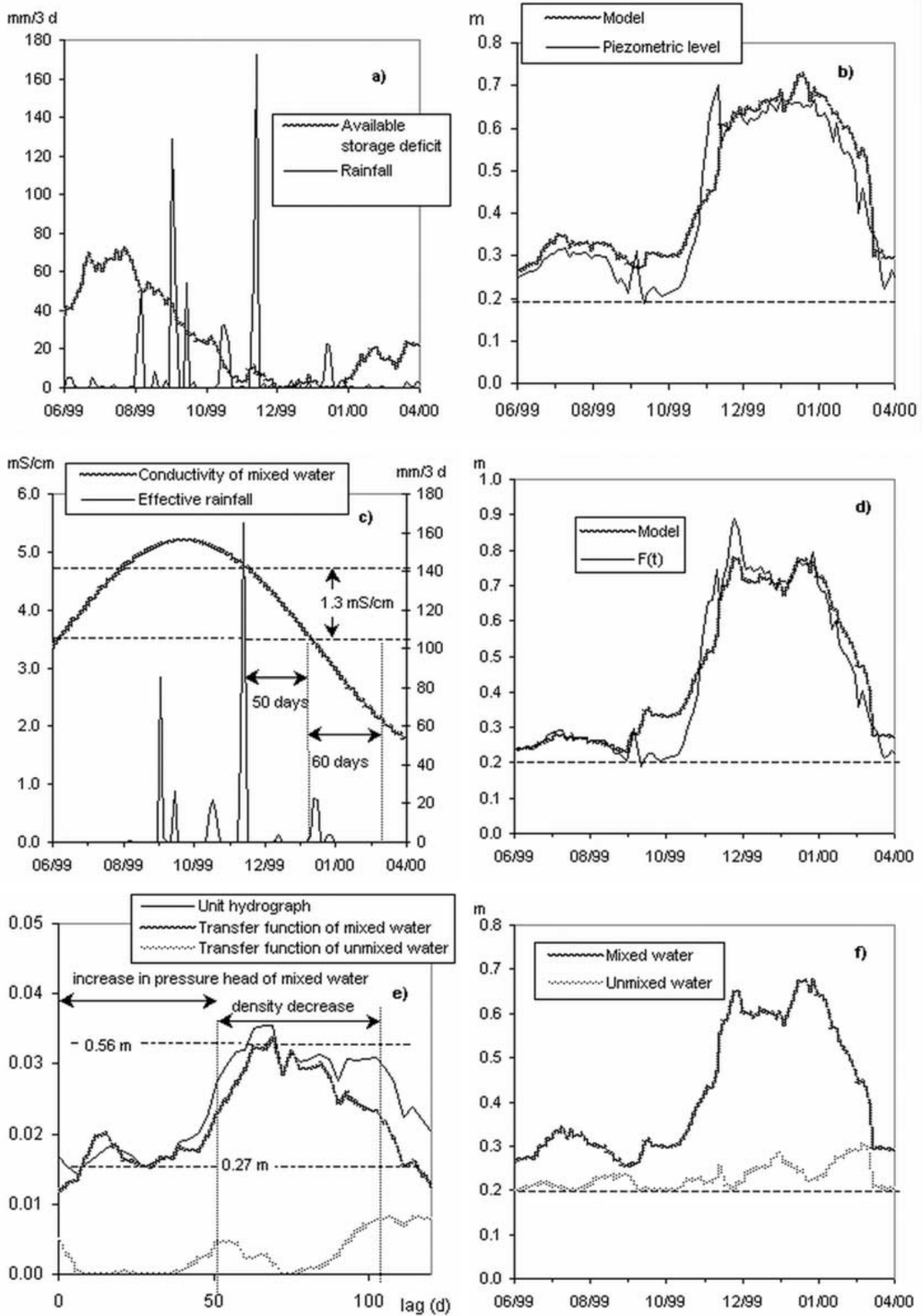

Figure 12. Data for La Vise spring. (a) Available storage deficit $\Omega$ and rainfall $\bar{R}_{\text {eff }}=0.48 \bar{R}$. (b) Comparison of the piezometric level and the model (Nash $=88 \%$ ). The reference level is $0.20 \mathrm{~m}$. (c) Trigonometric series representing the mixed water conductivity and effective rainfall. The reference value for conductivity is $0.8 \mathrm{mS} / \mathrm{cm}$. The delays corresponding to the alteration of the unit hydrograph behavior are represented after the rainfall events that occurred in November 1999: increase in the pressure head of the shallow confined aquifer and karst conduits caused by a density decrease in mixed water. (d) Comparison of the flux $F\left(t_{i}\right)$ and the model (Nash =93\%). (e) Unit hydrograph and weighted transfer functions. The weights associated with the transfer functions of mixed and unmixed waters are 0.88 and 0.12 , respectively. Dotted lines show the pressure head associated with the rainfall events of 12,13 , and 14 November 1999. (f) Hydrograph separation. 

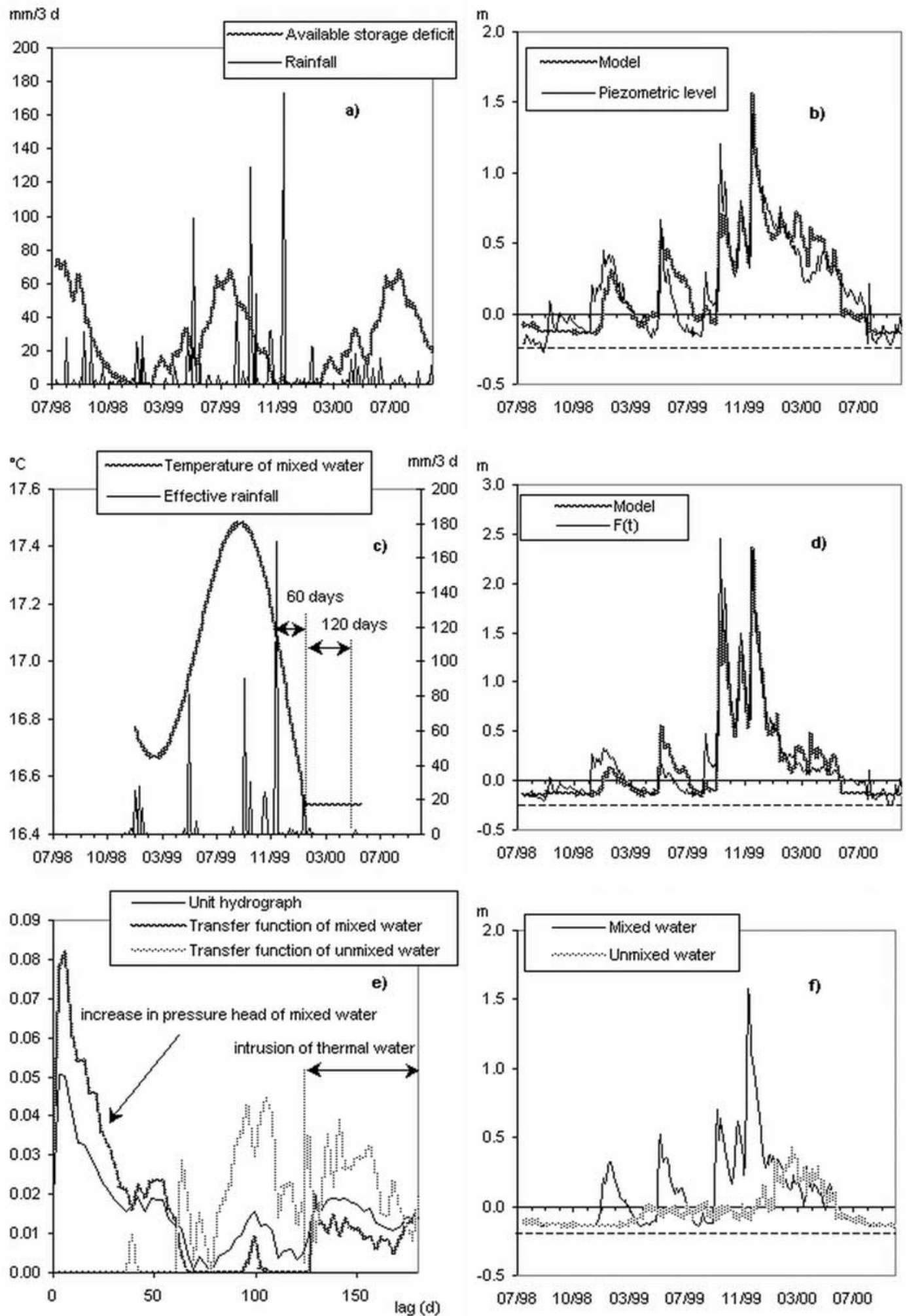

Figure 13. Data for Cauvy spring. (a) Available storage deficit $\Omega$ and rainfall $\bar{R}_{\text {eff }}=0.48 \bar{R}$. (b) Comparison of the piezometric level and the model (Nash $=81 \%$ ). The reference level is $-0.14 \mathrm{~m}$. (c) Trigonometric series representing the mixed water temperature and effective rainfall. The reference value for temperature is $16.5^{\circ} \mathrm{C}$. The delays corresponding to the alteration of the unit hydrograph behavior are represented after the rainfall events that occurred in November 1999: increase in the pressure head of the shallow confined aquifer and intrusion of thermal water into the karst conduits. (d) Comparison of the flux $F\left(t_{i}\right)$ and the model (Nash $=89 \%$ ). (e) Unit hydrograph and weighted transfer functions. The weights associated with the transfer functions of mixed and unmixed waters are 0.68 and 0.32, respectively. (f) Hydrograph separation. 
Table 3. Differences in the Functioning of the Springs

\begin{tabular}{|c|c|c|c|}
\hline Spring & $\begin{array}{l}\text { Main Driving Force for High } \\
\text { Storage }\end{array}$ & $\begin{array}{c}\text { Main Driving Force for Low } \\
\text { Storage }\end{array}$ & $\begin{array}{c}\text { Mixed } \\
\text { Water, \% }\end{array}$ \\
\hline Ambressac & $\begin{array}{l}\text { Pressure head in shallow } \\
\text { confined groundwater }\end{array}$ & Unmixed water flow & 30 \\
\hline La Vise & $\begin{array}{l}\text { Pressure head in shallow } \\
\text { confined groundwater }\end{array}$ & Water density decrease in conduits & 88 \\
\hline Cauvy & $\begin{array}{l}\text { Pressure head in shallow } \\
\text { confined groundwater }\end{array}$ & $\begin{array}{l}\text { Pressure head in deep groundwater } \\
\text { and unmixed water flow }\end{array}$ & 68 \\
\hline
\end{tabular}

results from a decrease in water density deduced from the conductivity of mixed water in Figure 12c. The density had decreased $0.0029 \mathrm{~g} / \mathrm{cm}^{3} 50$ days after the November rainfall event. This density is deduced from conductivity, assuming a linear relationship between both parameters (the density of water whose conductivity is $2.6 \mathrm{mS} / \mathrm{cm}$ is $1.0059 \mathrm{~g} / \mathrm{cm}^{3}$ ). An increase in the hydraulic head of about $0.29 \mathrm{~m}$ (Figure 12e) leads to an approximate depth of $100 \mathrm{~m}$ under the spring for the shallow reservoir in which thermal fluid mixes with shallow groundwater.

\subsection{Cauvy Spring}

[36] Unlike the Ambressac spring, the Cauvy spring is pumped, which causes a drawdown of $0.14 \mathrm{~m}$. The effective porosity $\omega_{e}$ calculated using equation (2) is $15.2 \%$. Figure $13 \mathrm{c}$ represents the trigonometric series of the mixed water temperature. Here again, the shape of both the unit hydrograph and the transfer function of mixed water suggest that the unit hydrograph represents mainly the mixed water reservoir discharge when the delay is less than 60 days (Figure 13e). The unmixed water component is therefore the part of the unit hydrograph that remains after the mixed water component has been subtracted. Equation (6) leads to $\Gamma_{\text {unmixed }}=\Gamma-0.68 \Gamma_{\text {mixed. }}$. Water temperature in the mixed water reservoir (Figure 13c) behaves like water conductivity in the reservoirs feeding the Ambressac and La Vise springs. Here the thermal water concentration is very low since mixed water temperature stays between $16.5^{\circ} \mathrm{C}$ and $17.5^{\circ} \mathrm{C}$, that is, a value very similar to the temperature of the shallow groundwater.

[37] The force driving the rising water column in this spring is the increase in pressure head in the shallow confined aquifer. The increase of the unit hydrograph after a 90-day delay is caused at first by the flow of unmixed water from the shallow aquifer then by the superposition of the flow of mixed and unmixed waters. Mixed water flow increases 120 days after the rainfall events, proving that there is intrusion of thermal water into the shallow reservoir (Figure 13e). As opposed to what occurs in La Vise spring, the renewal of thermal spring flow is not caused by the density effect in the mixed water reservoir. A reason for rejecting this hypothesis is the very low concentration of thermal water in the mixed water reservoir, significantly limiting water density variations. For low storage, therefore, the hydraulic heads both in the deep reservoir and in the confined shallow reservoir control spring flow.

\subsection{Hydrological System Functioning}

[38] Judging by variations in the mixed water flux in karst compartments of the aquifer that emerges at the
Ambressac, the Cauvy, and La Vise springs, these springs behave in a similar manner. They are all inundated by saline water when there is no effective rainfall and are diluted by the unmixed shallow groundwater after a significant rainfall event. This was exceptional after the rainfall events that occurred in September and November 1999 (Figures 10c, $12 \mathrm{c}$, and $13 \mathrm{c}$ ). The saline water reservoir is therefore always under pressure, and the increased flow in springs after a rainfall event is caused by the increase in the head of the shallow confined groundwater. The conduits in which the saline water rises are hydraulically connected to the shallow confined aquifer, and the piston flow effect is the principal driving force.

[39] However, spring functioning for low storage varies, and the phenomena observed are caused by the particularities of each individual spring (Table 3). For the Cauvy spring, a significant part of the flow is delayed because of thermal water intrusion into the mixed water reservoir, whose geometry cannot be determined because of the strong dilution of the saline water by the shallow groundwater. Consequently, no density effect in mixed water can be identified. The influence of mixed water density in spring flow is very great for La Vise spring, for which the transfer function of mixed water increases beyond 50 days then decreases slowly for 60 days while mixed water density continues to decrease in the reservoir. The mixed water reservoir feeding the Ambressac spring is very shallow since no density effect is perceptible while variations of mixed water conductivity are very great, which confirms the marine origin of saline water.

\section{Conclusions}

[40] Monitoring of three springs located in and around the Thau lagoon and inverse modeling of flow and fluxes greatly increased our understanding of this very complex groundwater system. Its complexity results from the convergence of deep thermal groundwater and marine water, as well as confined subsurface water, due mainly to the presence of deep karst conduits that developed during Neogene and Quaternary low sea level phases. The different forces driving the upward flowing mixed water into the drainage axis and faults were studied in order to determine their contribution to the spring functioning. A comparative study of spring functioning was proposed, which shows the very high sensitivity of the groundwater system to recharge variations and discharge conditions. The conceptual model presented here aims to highlight the constraints to be applied to the management of groundwater withdrawal in order to avoid disturbing this fragile equilibrium. 
[41] Acknowledgments. This study was carried out jointly by DIREN and BRGM and was funded by the General Council of the Hérault Department, the Rhône Méditerranée Corse Water Authority, and the Departmental Agriculture and Forest Directorate (with European Union ERDF funding). This work was done in part within the framework of BRGM's research program Structure and Functioning of Karstic Systems. We take the opportunity to thank sincerely both BRGM and DIREN technicians in charge of the groundwater monitoring.

\section{References}

Aquilina, L., B. Ladouche, N. Dörfliger, J. L. Seidel, M. Bakalowicz, C. Dupuy, and P. Le Strat (2002), Origin, evolution and residence-time of saline thermal fluids (Balaruc springs, southern France): Implications for large-scale fluid transfer, Chem. Geol., 192, 1-21.

Aquilina, L., B. Ladouche, N. Doerfliger, M. Bakalowicz, and J. L. Seidel (2003), Hydrochemistry of a complex karstic system: Thau lagoon (S. France), Ground Water, 41, 790-805.

Arfib, B. (2001), Etude des circulations d'eaux souterraines en aquifère karstique côtier: Observations et modélisation de la source saumâtre Almyros d'Héraklion, Crète (Grèce), Ph.D. thesis, 343 pp., Université Pierre et Marie Curie, Paris.

Arfib, B., G. de Marsily, and J. Ganoulis (2000), Pollution by seawater intrusion into a karst system: New research in the case of the Almyros source (Heraklio, Crete, Greece), Acta Carsologica, 29(1), 15-31.

Arfib, B., G. de Marsily, and J. Ganoulis (2001), Freshwater-saltwater motion in a coastal karstic aquifer: The case of the Almyros of Heraklio, Crete, Greece, paper presented at 1st International Conference on Saltwater Intrusion and Coastal Aquifers (SWICA M3), Int. Assoc. of Hydrogeol., Essaouira Maoco, Greece, 23-25 April.

Arthaud, F., and M. Séguret (1981), Les structures pyrénéennes du Languedoc et du Golfe du Lion (Sud de la France), Bull. Soc. Geol. Fr., 23, 51-63.

Auriol, J., P. Carlier, and J. P. Marchal (1988), Modélisation de l'aquifère karstique de l'étang de Thau, BRGM Internal Rep. 88SGN459LRO, Bur. Rech. Geol. Min., Orléans, France.

Baedke, S. J., and N. C. Krothe (2001), Derivation of effective hydraulic parameters of a karst aquifer from discharge hydrograph analysis, Water Resour. Res., 37(1), 13-19.

Bénédicto, A., P. Labaume, M. Séguret, and M. Séranne (1996), Low-angle crustal ramp and basin geometry in the Gulf of Lion passive margin: The Oligocene-Aquitanian Vistrenque graben, SE France, Tectonics, 15, $1192-1212$

Blanc, J.-J. (1997), Géodynamique et histoire du karst: Application au Sud-est de la France, Quaternaire, 8(2-3), 91-105.

Bonnet, A., and H. Paloc (1969), Les eaux des calcaires Jurassiques du bassin de Montbazin-Gigean et de ses bordures, Bull. Bur. Rech. Geol. Min. Fr. Sec. 3, 3, 1-12.

Breznik, M. (1973), The origin of the brackish karstic springs and their development, Geologija, 16, 83-186.

Breznik, M. (1998), Storage Reservoir and Deep Wells in Karst Regions, 251 pp., A. A. Balkema, Brookfield, Vt.

Brondi, M., M. Dall'aglio, and F. Vitrani (1973), Lithium as pathfinder element in the large scale hydrochemical exploration for hydrothermal systems, Geothermics, 2, 142-153.

Brondi, M., M. D. Fidelibus, R. Gragnani, and L. Tulipano (1983), Hydrogeochemical study and distribution of some trace elements in the most important coastal springs and groundwaters of the Apulian region, paper presented at 8 th Salt Water Intrusion Meeting, Univ. of Bari, Bari, Italy.

Choukroune, P. (1976), Structure et évolution tectonique de la zone nord-pyrénéenne, Mem. Soc. Geol. Fr., 55(127), 1-116.

Clauzon, G. (1990), Restitution de l'évolution géodynamique néogène du bassin du Roussillon et de l'unité adjacente des Corbières d'après les données écostratigraphiques et paléogéographiques, in Evolution Climatique Dans le Domaine Mediterraneen au Neogene, pp. 125-155, Paleobiol. Cont., Montpellier, France.

Dietrich, C. R., and T. G. Chapman (1993), Unit graph estimation and stabilization using quadratic programming and difference norms, Water Resour. Res., 29(8), 2629-2635.

Dreiss, S. J. (1982), Linear kernels for karst aquifers, Water Resour. Res., $18(4), 865-876$

Dreiss, S. J. (1989), Regional scale transport in a karst aquifer: 1. Component separation of spring flow hydrographs, Water Resour. Res., 25(1), $117-125$.

Drogue, C., and P. Bidaux (1986), Simultaneous outflow of fresh water and inflow of sea water in a coastal spring, Nature, 322, 361-363.
Dubois, P. (1964), Esquisse de l'hydrogéologie du massif de la Gardiole, Bas Languedoc, Spelunca, 3, 57-67.

Gèze, B. (1973), Lexique des termes français de spéléologie et de karstologie, Ann. Speleol., 28(1), 1-20.

Gèze, B. (1987), Les mésaventures des sources de l'Estavelle et de l'Inversac en Languedoc méditerranéen, Int. J. Speleol., 16, 101109.

Gilli, E. (1999), Détection des sources sous-marines et pécision de l'impluvium par mesures des variations de salinité: L'exemple de la source de Cabbé-Massolins (Roquebrune-Cap-Martin, France), C. $R$. Acad. Sci., Ser. IIa Sci. Terre Planetes, 329(2), 109-116.

Guennoc, P., N. Debeglia, A. Le Marrec, C. Gorini, and A. Mauffret (1994), Anatomie d'une marge passive jeune (Golfe du Lion, Sud-France): Apports des données géophysiques, Bull Cent. Rech. Explor. Prod. Elf Aquitaine, 18, 19-32.

Kiraly, L. (1975), Report on the current knowledge in the domain of physical properties of karstic rocks, Hydrogeology of Karstic Terrains, Ser. B Int. Union of Geol. Sci., vol. 3, edited by A. Burger and L. Dubertret, pp. 53-67, Int. Assoc. of Hydrogeol., Paris.

Krimissa, M., L. Chery, C. Fouillac, and J. L. Michelot (1995), Origin and recharge altitude of the thermo-mineral waters of the eastern Pyrénées, Isotopenpraxis, 30, 1-15.

Ladouche, B., M. Bakalowicz, N. Courtois, N. Doerfliger, J. L. Pinault, P. Chemin, and S. Anus (2001), Étude du pourtour est de l'étang de Thau, phase II: Fonctionnement hydrogéologique du bassin karstique de Thau, BRGM Rep. RP-50787-FR, vol. 2, 275 pp., Bur. Rech. Geol. Min., Orléans, France.

Lakey, B., and N. C. Krothe (1996), Stable isotopic variation of storm discharge from a perennial karst spring, Water Resour. Res., 32(3), $721-731$.

Larocque, M., A. Mangin, M. Razack, and O. Banton (1998), Contribution of correlation and spectral analyses to the regional study of a large karst aquifer (Charente, France), J. Hydrol., 205, 217-231.

McLaughlin, D., and L. R. Townley (1996), A reassessment of the groundwater inverse problem, Water Resour. Res., 32(5), 1131-1162.

Michard, G., and E. Roekens (1983), Modelling of the chemical composition of alkaline hot waters, Geothermics, 12, 161-169.

Mijatovic, B. F. (1986), Problèmes de captages en régions karstiques littorales, Bull. Cent. Hydrogeol. Univ. Neuchâtel, 7, 65-106.

Milanovic, P. T. (1981), Karst Hydrogeology, 434 pp., Water Resour. Publ., Highlands Ranch, Colo.

Morozov, V. A. (1984), Methods for Solving Incorrectly Posed Problems, Springer-Verlag, New York.

Padilla, A., A. Pulio-Bosch, and A. Mangin (1994), Relative importance of baseflow and quickflow from hydrographs and karst springs, Ground Water, 32, 267-277.

Paloc, H., and L. Potié (1974), Etat des connaissances sur les sources littorales et sous-marines, Rep. BRGM-SEM RR22614-FR, 65 pp., Bur. Rech. Geol. Min., Orléans, France.

Pinault, J.-L. (2001) Manuel utilisateur de TEMPO: Logiciel de traitement et de modélisation des séries temporelles en hydrogéologie et en hydrogéochimie, Projet Modhydro, Rep. BRGM/RP-51459-FR, 221 pp., Bur. Rech. Geol. Min., Orléans, France.

Pinault, J.-L., H. Pauwels, and C. Cann (2001a), Inverse modeling of the hydrological and the hydrochemical behavior of hydrosystems: Application to nitrate transport and denitrification, Water Resour. Res., 37(8), 2179-2190.

Pinault, J.-L., V. Plagnes, L. Aquilina, and M. Bakalowicz (2001b), Inverse modeling of the hydrological and the hydrochemical behavior of hydrosystems: Characterization of karst system functioning, Water Resour. Res., 37(8), 2191-2204.

Potié, L., and J. Ricour (1973a), Etudes et captage de résurgences d'eau douce sous-marines: A suivre, Rev. Techn. Int. Eau, 10, 5-15.

Potié, L., and J. Ricour (1973b), Etudes et captage de résurgences d'eau douce sous-marines: Suite, Rev. Techn. Int. Eau, 11, 7-18.

Séranne, M. (1999), The Gulf of Lion continental margin (NW Mediterranean) revisited by IBS: An overview, in The Mediterranean Basins: Tertiary Extension Within the Alpine Orogeny, edited by B. Durand et al., Geol. Soc. London Spec. Publ., 156, 15-36.

Séranne, M., A. Bénédicto, P. Labaum, C. Truffer, and G. Pascal (1995), Structural style and evolution of the Gulf of Lion Oligo-Miocene rifting: Role of the Pyrenean orogeny, Mar. Pet. Geol., 12(8), 809820 .

Tadolini, T., and L. Tulipano (1981), The evolution of fresh-water saltwater equilibrium in connection with withdrawals from the coastal carbonate and karstic aquifer of the Salentine peninsula (southern Italy), Geol. J., 29, 69-85. 
Tikhonov, A., and V. Arsenine (1976), Méthodes de Résolution de Problèmes Mal Posés, MIR, Moscow.

Tikhonov, A. N., and A. V. Goncharsky (Eds.) (1987), Ill-Posed Problems in the Natural Sciences, MIR, Moscow.

Tulipano, L., and M. D. Fidelibus (2002), Mechanisms of groundwater salinisation in a coastal karst aquifer subject to over-exploitation, 17th Salt-Water Intrusion Meeting (SWIM), Univ. of Delft, Delft, Netherlands.

Vuataz, F. D. (1983), Hydrology, geochemistry and geothermal aspects of the thermal waters from Switzerland and adjacent alpine regions, J. Volcanol. Geotherm. Res., 19, 73-97.

White, W. B. (1999), Conceptual models for karstic aquifers, in Karst Modeling: Proceedings of the Symposium Held February 24 through
27, 1999, Charlottesville, Virginia, Spec. Publ., vol. 5, edited by A. N. Palmer, M. V. Palmer, and I. D. Sasowsky, pp. 11-16, Karst Waters Inst., Charles Town, W. Va.

M. Bakalowicz, Hydrosciences, Maison des Sciences de l'Eau, Université Montpellier II, F-34000 Montpellier, France. (m.bakalowicz@ brgm.fr)

N. Doerfliger and B. Ladouche, Service Eau, BRGM, 1039 rue de Pinville, F-34000 Montpellier, France. (n.dorfliger@brgm.fr; b.ladouche@ brgm.fr)

J.-L. Pinault, BRGM, Service Eau, BRGM, 3 av. Cl. Guillemin, F-45060 Orléans cedex, France. (jl.pinault@brgm.fr) 


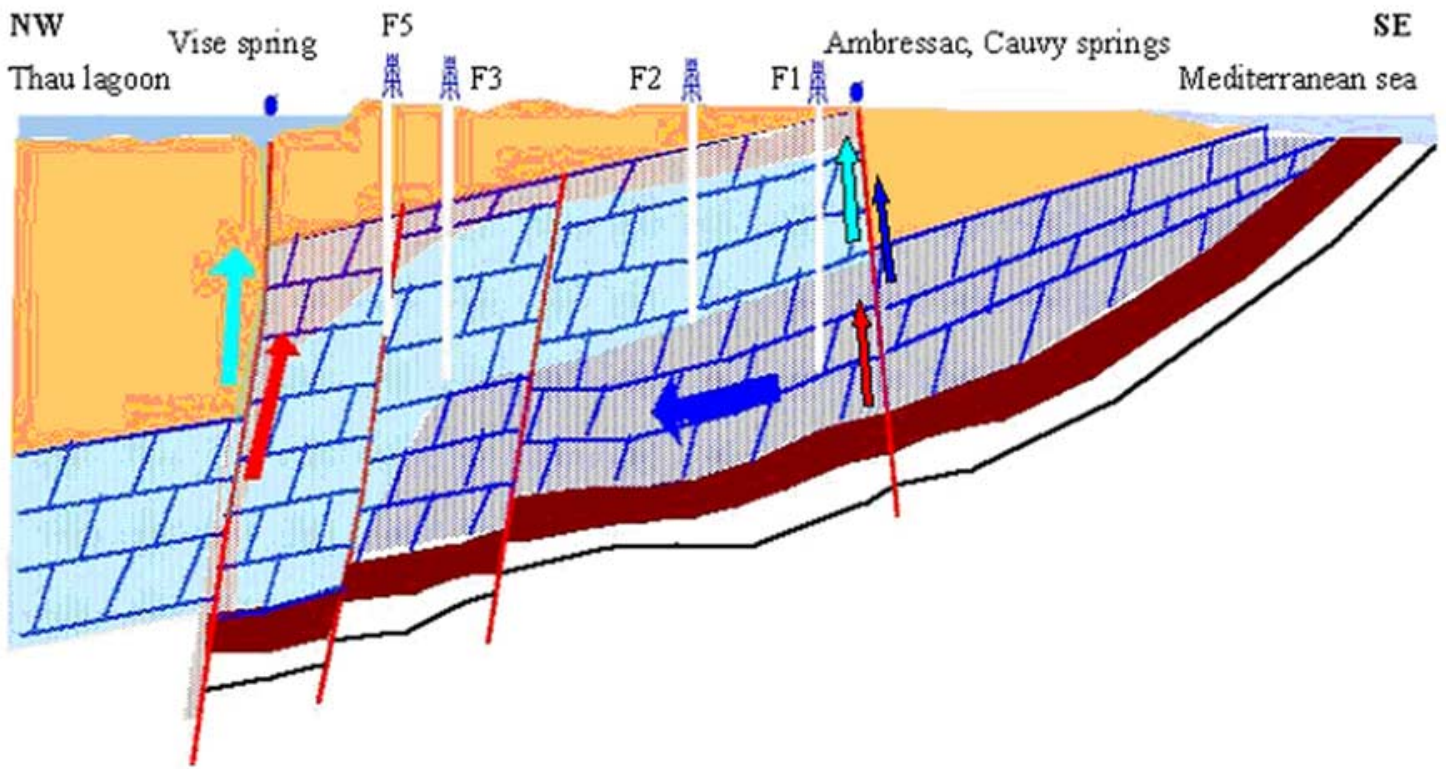

Legend

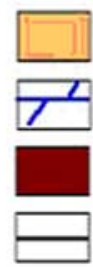

Pliocene

Upper Jurassic

Clayey limestone

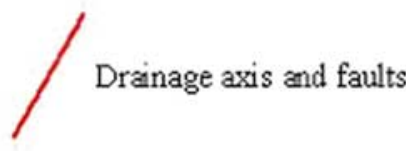

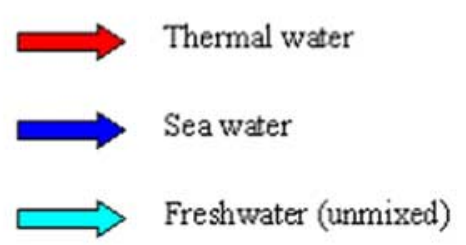

Freshwater (unmixed)

Figure 6. Schematic cross section showing groundwater flow in the Thau karst system. Some of the groundwater infiltrates deeply and acquires the signature of thermal water before rising in karst conduits because of the pressure head exerted by the infiltrating water. Confined groundwater moves upward through the karst conduits because of both the hydraulic head under high storage conditions and a density decrease of mixed water (thermal water, seawater, and freshwater) in the shallow reservoir. Unmixed freshwater or mixed water may feed the springs according to the storage conditions. The Pliocene cover is impermeable, and recharge of shallow groundwater occurs from the Causse d'Aumelas and Gardiole Mountain (Figure 3). 